\author{
MARTA KLIMASZYK \\ Uniwersytet Ekonomiczny w Poznaniu, Polska \\ Poznań University of Economics and Business, Poland \\ MARCIN OLSZEWSKI \\ Uniwersytet Ekonomiczny w Poznaniu, Polska \\ Poznań University of Economics and Business, Poland
}

\title{
Wykorzystanie metody zdarzeń krytycznych do oceny doświadczeń konsumentów w parkach rozrywki
}

\section{Critical Incident Technique application for customer experience evaluation in theme parks}

\begin{abstract}
Streszczenie: Celem artykułu jest identyfikacja możliwości wykorzystania metody zdarzeń krytycznych do oceny antecedencji i efektów doświadczeń konsumentów w parkach rozrywki. Na przykładzie Parku Energylandia w Zatorze zidentyfikowano charakter doświadczeń i przeprowadzono ich autorską typologizację. W badaniu analizie poddano 295 zdarzeń zidentyfikowanych w 150 komentarzach pozostawionych przez odwiedzających park rozrywki na portalu TripAdvisor. Artykuł składa się z 4 części poprzedzonych wstępem. Na początku przybliżono znaczenie zarządzania doświadczeniem konsumenta. W kolejnej części przedstawiono istotę parków rozrywki i ich typologię. Następnie opisano metodę zdarzeń krytycznych wraz z przykładami jej zastosowań w turystyce oraz przedstawiono metodologię autorskiego badania, wyniki i wnioski. Wykorzystana metoda badawcza pozwoliła na pogłębioną ocenę doświadczeń klientów parku rozrywki wraz ze wskazaniem ich charakteru, a także uwarunkowań. W pracy wskazano także rekomendacje dla praktyki i kierunki dalszych badań wykorzystujących metodę zdarzeń krytycznych do oceny doświadczeń w turystyce.
\end{abstract}

\begin{abstract}
The aim of the article is to identify the possibility of using the critical incident technique to assess the antecedence and effects of consumer experiences in amusement parks. Based on the example of the Energylandia Park in Zator, the nature of the experiments was identified and their original typologisation was carried out. The study analysed 295 incidents identified in 150 comments left by visitors to the amusement park on the TripAdvisor portal. The article consists of 4 parts preceded by an introduction. At the beginning, the importance of managing the consumer experience was introduced. The next part presents the essence of amusement parks and their typology. Then the technique of critical incident was introduced, along with examples of its applications in tourism, and the methodology of the original research, results and conclusions were presented. The research method used allowed for an in-depth assessment of the experiences of the amusement park customers along with an indication of their nature and conditions. The paper also indicates recommendations for further research using the critical incident technique to assess experiences in tourism.
\end{abstract}

Słowa kluczowe: doświadczenie; metoda zdarzeń krytycznych; parki rozrywki; usługi turystyczne Keywords: critical incident technique; experience; theme parks; tourism services 
Otrzymano: 10 lipca 2021

Recived: 10 July 2021

Zaakceptowano: 23 lipca 2021

Accepted: 23 July 2021

Sugerowana cytacja / Suggested citation:

Klimaszyk, M., Olszewski, M. (2021). Wykorzystanie metody zdarzeń krytycznych do oceny doświadczeń konsumentów w parkach rozrywki. Prace Komisji Geografii Przemysłu Polskiego Towarzystwa Geograficznego, 35(3), 100-115, doi: https://doi.org/10.24917/20801653.353.7

\section{WSTĘP}

Doświadczenie konsumenta w turystyce jest zjawiskiem badanym od wielu lat (Agapito, Mendes, Valle, 2013; Tung, Ritchie, 2011). Dotychczasowe prace poświęcone były doświadczeniom w hotelarstwie (Gilmore, Pine, 2002), gastronomii (Arora, 2012), czy w regionach turystycznych (Cetin, Bilgihan, 2016). Jednym z podmiotów, w którym rola doświadczeń jest szczególnie istotna, są parki rozrywki (Fu i in., 2020; Wei i in., 2021).

Doświadczenie w odniesieniu do turystyki definiowane jest dwojako (Adhikari, Bhattacharya, 2016). Z jednej strony rozumiane jest jako produkt i jego atrybuty (Gilmore, Pine, 2002). Z drugiej strony, traktuje się je jako efekt interakcji konsumenta z elementami materialnymi i ludźmi - personelem lub innymi konsumentami (Kastenholz, Davis, Paul, 1999). Innym sposobem klasyfikacji doświadczenia jest podział na podejście prospektywne i retrospektywne (Adhikari, Bhattacharya, 2016). W tym pierwszym doświadczenie postrzegane jest jako oczekiwanie klienta związane z jego zaangażowaniem sensorycznym w produkt lub interakcję, którą ma przeżyć. Badacze definiujący doświadczenie klienta z perspektywy retrospektywnej zajmują się doświadczeniem klienta $\mathrm{w}$ trakcie lub po konsumpcji produktu lub interakcji sensorycznej (Bos, McCabe, Johnson, 2013).

Jak zauważają Stangierska i Górska-Warsewicz (2016: 128) ważne jest pojmowanie doświadczenia jako wewnętrznej i subiektywnej odpowiedzi na bezpośrednią lub pośrednią interakcję zachodzącą między przedsiębiorstwem a konsumentem podczas trwania ich wzajemnej relacji. Prowadzi to do zaangażowania konsumentów nie tylko na poziomie racjonalnym, ale również emocjonalnym, zmysłowym, fizycznym i duchowym. Złożona struktura zdobywanego doświadczenia sprawia, że każde, pojedyncze doświadczenie jest inne i z tego powodu należy próbować łączyć doświadczenia w grupy o podobnych cechach. Takiemu założeniu odpowiada opracowana przez Schmitt'a (1999) koncepcja strategicznych modułów doświadczeń, w skład której wchodzą:

- moduł sensoryczny (sense) - odwołuje się do ludzkich zmysłów (wzroku, słuchu, węchu, smaku i dotyku) w celu tworzenia zmysłowych doświadczeń. W tym wypadku istotne jest wykorzystywanie wszystkich bodźców w sposób zapewniający spójność poznawczą i zmysłową różnorodność;

- moduł emocjonalny (feel) - odwołuje się do ludzkich uczuć i emocji w celu wywołania afektywnych doświadczeń, które oscylują od umiarkowanie pozytywnych nastrojów po silne emocje. W tym wypadku istotne jest określenie, jakie bodźce pobudzają emocje, a także, jakie są to emocje i jaki wpływ wywierają na konsumenta; 
- moduł intelektualny (think) - odwołuje się do ludzkiego intelektu w celu wywołania doświadczeń poznawczych wymagających myślenia i twórczego zaangażowania ze strony konsumentów. W tym wypadku istotne jest precyzyjne określenie odbiorcy komunikacji i kontekstu, w jakim będzie się odbywać;

- moduł behawioralny (act) - odwołuje się do racjonalnego sposobu myślenia, bądź dostarcza motywacji, inspiracji lub wskazuje wzorce w celu wzbogacenia życia konsumentów poprzez doświadczenia natury fizycznej, pozwalające na odkrycie i zmianę stylu życia, zachowań, interakcji, czy sposobów wykonywania określnych działań;

- moduł relacyjny (relate) - odwołuje się do występowania powiązań pomiędzy jednostką a innymi ludźmi bądź grupami społecznymi, wykracza jednak poza indywidualne interakcje wynikające z pozostałych modułów i przedstawia konsumenta w szerszym społeczno-kulturowym kontekście w celu budowania relacji pomiędzy nim a społecznym znaczeniem marki.

Złożony charakter doświadczeń sprawia, że ich pomiar staje się poważnym wyzwaniem i wymaga dalszych badań (Adhikari, Bhattacharya, 2016). Istotne jest nie tylko określenie, jaki charakter mają doświadczenia konsumenta w przedsiębiorstwie (pozytywny czy negatywny), ale także jaka jest ich struktura (Otto, Ritchie, 1996). Pomiar doświadczeń jest szczególnie ważny w parkach rozrywki, których produkt Adhikari i Bhattacharya (2016) określili jako czyste doświadczenie (pure experience). Do pomiaru doświadczeń stosuje się różne metody. Jedną z nich jest metoda zdarzeń krytycznych, która pozwala na uchwycenie najbardziej zapamiętanych aspektów doświadczenia. Jej zastosowanie we wcześniejszych badaniach nad doświadczeniem w parkach rozrywki nie jest częste (np. Niu, Park, Kirilenko, 2019), jednak zalety tej metody (Gremler, 2004) pozwalają uznać ją jako obiecującą do pogłębionej analizy doświadczeń klientów parków rozrywki.

Biorąc powyższe pod uwagę, celem artykułu jest identyfikacja możliwości wykorzystania metody zdarzeń krytycznych do oceny doświadczeń konsumentów w parkach rozrywki. Na przykładzie Parku Energylandia w Zatorze zidentyfikowano charakter doświadczeń i przeprowadzono ich autorską typologizację, a także wskazano ich antecedencje i oczekiwane efekty.

\section{PARKI ROZRYWKI JAKO PRZYKŁAD ATRAKCJI TURYSTYCZNYCH}

Obecnie, zarówno w Polsce, jak i na całym świecie, można zaobserwować coraz większe zainteresowanie atrakcjami typu parki rozrywki, które oferują zróżnicowane i intensywne doświadczenia dla klientów (Wei i in., 2021). Przykłady na świecie pokazują, że pomimo ogromnej kapitałochłonności, zwłaszcza na etapie budowy parku, zwrot poniesionych kosztów jest niemal pewny (Doroz-Tomasik, Jankowski, 2016). Poza wymiarem finansowym ważny jest też aspekt społeczny. Parki tematyczne są czynnikiem aktywizacji społeczności lokalnych, pobudzając inicjatywy: prywatne, komunalne; stając się środkiem w poszukiwaniu nowych dróg rozwoju i rozwiązywania problemów społecznych, gospodarczych, demograficznych. Samorządy terytorialne coraz częściej sięgają po nie, walcząc z problemami finansowymi, bezrobociem czy wykluczeniem społecznym mieszkańców (Rzeńca, 2012: 411).

Pierwowzorem parków tematycznych (theme park), zwanych też parkami rozrywki (amusement park) były wesołe miasteczka z kolejkami (roller coaster) oraz 
różnymi interesującymi eksponatami do oglądania (Kruczek, 2012). Główną różnicą pomiędzy nimi a obecnymi parkami jest skala. Parki rozrywki rozciągają się na ogromnych terenach, często zajmują obszar porównywalny z małymi miastami. Poza tym jest w nich więcej atrakcji, na ogół bardziej ekscytujących i technicznie bardziej zaawansowanych niż w tradycyjnych wesołych miasteczkach.

Kruczek (2012: 30) za: Pearce (2003), definiuje park rozrywki jako „kapitałochłonne, wysoko rozwinięte, samodzielne przestrzenie rekreacyjne, które pobierają opłatę za wstęp". Autor powyższej definicji podkreśla też znaczenie tematu czy motywu przewodniego takich obiektów oraz funkcje, jaką mają one pełnić - ucieczka od codzienności. Parki rozrywki to przestrzenie rekreacyjne pełniące określone funkcje (w tym funkcję rozrywkową), zaaranżowane zgodnie z tematem lub tematami przewodnimi; przestrzenie te są wyraźnie wydzielone $\mathrm{z}$ otaczającego krajobrazu poprzez specyficzny styl infrastruktury i urządzeń, a ich izolacja potęgowana jest wyznaczeniem wyraźnych granic (Doroz-Tomasik, Jankowski, 2016: 24). Większość dochodów w parkach rozrywki pochodzi ze sprzedaży biletów wstępu, które nie obejmują strefy gastronomicznej, zazwyczaj towarzyszącej tego typu obiektom (Kruczek, 2012). Park rozrywki jest zatem kompleksem zawierającym różne strefy tematyczne, oferujące turystom liczne atrakcje turystyczne w postaci kolejek górskich, rodzinnych, czy rollercoasterów o zróżnicowanym stopniu dostarczanych wrażeń. Jest to miejsce, w którym kupując jeden bilet wstępu, uzyskuje się dostęp do większości atrakcji, a strefy towarzyszące są dodatkowo płatne. Obiekty te zlokalizowane są najczęściej w okolicy małych miasteczek, z racji na ogromny teren, jaki zajmują. Doroz-Tomasik i Jankowski (2016) proponują podział parków na 5 typów:

1. Rozrywkowe parki tematyczne, których funkcją jest wyłącznie dostarczanie odwiedzającym zabawy i wrażeń podnoszących poziom adrenaliny, za pomocą wykorzystania różnego rodzaju kolejek typu rollercoaster.

2. Edukacyjne parki rozrywki, czyli obiekty, które oferują przede wszystkim naukę przez zabawę. Jak wskazuje nazwa, najważniejszą funkcją takich parków jest funkcja edukacyjna.

3. Historyczne parki tematyczne, łączące interaktywność zwiedzania z pielęgnowaniem regionalnego dziedzictwa kulturowego. Główną funkcją jest również edukacja.

4. Parki aktywnej rekreacji, gdzie dominująca jest funkcja rekreacyjna, a dokładniej możliwość uprawiania różnego rodzaju aktywności fizycznej, np. parki wodne.

5. Mieszane parki tematyczne, gdzie nie można jednoznacznie określić funkcji. Najczęściej łączą kilka naraz, np. edukacyjną z rekreacyjną.

Tchorek, Kulykovets, Górska-Warsewicz (2016: 287) za Clave (2007) zaproponowały inną typologię parków rozrywki biorąc pod uwagę skalę oddziaływania i atrakcyjność parku. Są nimi:

1. „Parki destynacje - specjalnie zaprojektowane, aby przyciągnąć jak największą liczbę turystów z pobliskich miast i dalszych miejscowości, których pobyt nastawiony jest także na nocleg w danej destynacji, a odwiedziny obiektu są głównym powodem przyjazdu turysty.

2. Regionalne parki - funkcjonujące w określonym terminie, przyciągające znaczną liczbę turystów w ciągu kilku godzin dziennie. Większość odwiedzających park pochodzi z miejscowości oddalonych o 100-200 km. 
3. Parki lokalne - odwiedzane głównie przez mieszkańców pobliskich miejscowości. Są uboższe tematycznie, czasem zorientowane na tematykę lokalną.

4. Niszowe parki rozrywki - nieprzystosowane do dużej liczby odwiedzających. Ich funkcjonowanie uwarunkowane jest poziomem rozwoju miejscowej infrastruktury. Potencjał turystyczny parku jest niewielki, a lista atrakcji - uboga. Często takie parki zorientowane są na ofertę wakacyjną".

De Groote (2011) zaproponował klasyfikację atrakcji, które można spotkać w parkach rozrywki. Są nimi atrakcje z dreszczykiem emocji (thrill ride), np. karuzele, huśtawki, wieże swobodnego spadania i diabelskie młyny, rollercoastery (kolejki górskie), atrakcje wykorzystujące wodę i obiekty pływające (water attractions), przejażdżki w zadaszonych miejscach (indoor dark rides), np. domy strachu oraz atrakcje dostępne dla wszystkich grup wiekowych (family ride), np. kolejki i karuzele.

Kluczem do sukcesu parków rozrywki jest zdolność do tworzenia unikalnych doświadczeń. Dotychczasowe badania prowadzone wśród klientów parków rozrywki koncentrowały się na identyfikacji źródeł zadowolenia klientów. Ma i in. (2013) na podstawie badania 645 respondentów zidentyfikowali ścieżki prowadzące do zachwytu gości w parku rozrywki. Dong i Siu (2013) przebadali 366 osób w dwóch parkach poszukując antecedencji i efektów doświadczeń związanych z obsługą klienta dla odwiedzających parki rozrywki. Niu, Park i Kirilenko (2019) wykorzystując ponad 40 tysięcy opinii na portalu TripAdvisor zidentyfikowali główne wątki pojawiające się w recenzjach trzech parków rozrywki USA.

Zarządzanie doświadczeniem klienta w parkach rozrywki nakłada na prowadzących takie obiekty konieczność badania tego, jak je postrzegają goście. Kluczowe jest poznanie, jaki charakter mają doświadczenia konsumentów, co o nich decyduje, czego dotyczą, a także jakie skutki mogą z nich wynikać. Jednym z potencjalnych narzędzi takiego badania jest metoda zdarzeń krytycznych. Możliwości jej zastosowania do oceny doświadczeń w parkach rozrywki sprawdzone zostały w badaniu przeprowadzonym na potrzeby tego artykułu.

\section{METODA ZDARZEŃ KRYTYCZNYCH I JEJ ZASTOSOWANIE W TURYSTYCE}

Metoda zdarzeń krytycznych (critical incident technique - CIT) została opracowana przez Flanagana (1954) w celu doboru i klasyfikacji załóg lotniczych. Zdaniem jej autora zdarzenie to „każde obserwowalne działanie ludzkie” (Flanagan, 1954: 1). Staje się ono krytyczne, gdy jest możliwe do oceny i powoduje pozytywny lub negatywny wkład w cel działania. Sama metoda jest bardzo ogólnie definiowana przez jej twórcę jako „procedura zbierania ważnych faktów dotyczących zachowania w określonych sytuacjach" (Flanagan, 1954: 9). Jej celem jest zrozumienie zdarzenia z perspektywy jednostki, z uwzględnieniem elementów poznawczych, afektywnych i behawioralnych (Gremler, 2004).

W odniesieniu do badania doświadczeń konsumenta można przyjąć, że polega ona na analizowaniu (rekonstruowaniu) kluczowych interakcji, jakie zachodzą pomiędzy klientem a usługodawcą. Wszelkie interakcje mogą mieć dla konsumenta usługi wydźwięk pozytywny (są źródłem satysfakcji), bądź negatywny (są źródłem frustracji). CIT jest metodą identyfikującą problemy występujące w przedsiębiorstwie, która bazuje w głównej mierze na obserwacji i analizie zachowań ludzkich. W ramach tego podejścia respondenci proszeni są o opowiedzenie historii o doświadczeniu, które ich 
spotkało (Gremler, 2004). Aby zdarzenie zostało uznane za krytyczne, muszą zajść następujące przesłanki (Dziadkowiec, 2006):

- występuje interakcja pomiędzy klientem a pracownikiem przedsiębiorstwa,

- zdarzenie jest bardzo zadowalające lub bardzo niezadowalające z punktu widzenia klienta,

- zdarzenie jest odrębnym epizodem,

- zdarzenie jest na tyle odrębnym faktem, że prowadzący badanie jest w stanie je sobie wyobrazić.

W turystyce metoda ta stosowana była do oceny zdarzań krytycznych w hotelach, restauracjach, czy w transporcie (Baker, Kim, 2016; Jackson, White, Schmierer, 1996; Jackson, 2019; Zainol, Lockwood, 2014). Jednym z podstawowych wyzwań stojących przed badaczami wykorzystującymi metodę zdarzeń krytycznych jest określenie sposobu klasyfikacji i interpretacji doświadczeń.

Pearce i Caltabiano (1983) do analizy doświadczeń wykorzystali model potrzeb Maslowa. Jak wynika z tych badań, struktura pozytywnych i negatywnych doświadczeń nie jest identyczna. Turyści postrzegali pozytywne doświadczenia przede wszystkim na podstawie trzech potrzeb: fizjologicznych (hedonistyczne aktywności), miłości i przynależności (wzmocnienie istniejących relacji), oraz potrzeb samorealizacji (lepsze zrozumienie siebie i kultury kraju goszczącego). W przypadku negatywnych doświadczeń, turyści skupiali się na błędach w zapewnieniu podstawowych potrzeb (np. w usługach takich jak transport, noclegi i wyżywienie).

Jackson, White i Schmierer (1996) podzielili przypadki na wewnętrzne (osobowe), międzyludzkie i związane ze środowiskiem zewnętrznym (otoczenie). Pozytywne przypadki dotyczyły czynników wewnętrznych (zrozumienie kultury i dziedzictwa, wolność i możliwość relaksu), czynników interpersonalnych (pozytywne relacje między gospodarzem a turystą, przyjazne relacje międzyludzkie) oraz zewnętrznych (obecność środowiska naturalnego, i dziedzictwa kulturowego). Te trzy czynniki zdominowały również najbardziej negatywne (najgorsze) doświadczenia turystyczne. $\mathrm{Na}$ przykład, czynniki osobowe obejmowały m.in doświadczanie strachu, czy dyskomfortu emocjonalnego związanego z odkrywaniem nowych miejsc. Czynniki interpersonalne obejmowały szeroki zakres negatywnych relacji międzyludzkich (rodzina, przyjaciele, inni turyści, gospodarze i przedstawiciele branży turystycznej). Wreszcie, negatywne doświadczenia związane z zewnętrznymi czynnikami środowiskowymi obejmowały niesprzyjającą pogodę, niski standard zakwaterowania lub awarie.

Jackson (2019) wykorzystując metodę CIT na podstawie teorii atrybucji potwierdził występowanie tzw. błędu atrybucji, który zakłada, że pozytywne doświadczenia wyjaśniane są przede wszystkim czynnikami wewnętrznymi, a negatywne doświadczenia - czynnikami tkwiącymi w otoczeniu.

Do kluczowych zalet metody zdarzeń krytycznych w kontekście oceny doświadczeń należą: zróżnicowane możliwości pozyskiwania danych (ankiety, wywiady, dane wtórne), niskie koszty, prostota, szeroki zakres pozyskanych informacji oraz możliwość identyfikacji przyczyn problemów, a nie tylko ich przejawów (Gremler, 2004; Jackson, 2019). Ważne jest także to, że dane są zbierane z perspektywy respondenta, jego własnymi słowami. Stosując tę metodę nie wtłacza się respondentów w żadne ramy teoretyczne i można zidentyfikować nawet rzadkie zdarzenia, które mogłyby zostać przeoczone przez inne metody, koncentrujące się tylko na zdarzeniach powszechnych. 


\section{METODOLOGIA BADANIA}

W tej części przedstawiona została procedura autorskiego badania przeprowadzonego w oparciu o metodę zdarzeń krytycznych. Pozwoliło ono uzyskać odpowiedź na następujące pytania:

- Co składa się na doświadczenie klienta parku rozrywki? Jakie są antecedencje doświadczeń?

- Jakie są deklarowane skutki doświadczeń? Co z nich może wynikać dla przedsiębiorstw?

- W jakim stopniu zastosowana metoda zdarzeń krytycznych może przyczynić się do identyfikacji antecedencji i efektów doświadczeń klientów parków rozrywki?

Przyjęta procedura badania została opracowana na podstawie pracy Zainol i Lockwood (2014) i obejmowała 3 etapy: zbieranie danych; analiza, interpretacja i wnioskowanie. Postępując zgodnie z przyjętą procedurą, w pierwszej kolejności zgromadzono materiał w postaci komentarzy umieszczonych na portalu TripAdvisor pod profilem parku rozrywki Energylandia w Zatorze, która stanowi zakres podmiotowy analizy. Wykorzystanie portali internetowych do badania pozwala na wgląd $\mathrm{w}$ faktyczne historie opowiedziane przez klientów, nie wymaga kosztownego pozyskiwania danych $\mathrm{w}$ terenie i nie wiąże się z błędami związanymi z obecnością badacza. Metoda ta, ze względu na swoje zalety, bywa wykorzystywana do badań doświadczeń (Niu, Park, Kirilenko, 2019). Dane gromadzono w maju 2021 roku, a zakres czasowy badania został ustalony na rok 2019, od 1 stycznia do 31 grudnia tj. ostatni pełny rok normalnej działalności parku.

Do określenia liczebności badanych przypadków zastosowano zasadę „nasycenia treści"; tj. jeśli kolejny komentarz nie wnosi nowej treści, a jedynie odnosi się do wcześniej już wspominanych aspektów, należy badanie zakończyć (Baker, Kim, 2016). W efecie selekcji do badania zakwalifikowano 150 przypadków opisujących różne doświadczenia. Łączna liczba zdarzeń umieszonych w badanych komentarzach wyniosła 295.

Kolejnym etapem badania było ustalenie sposobu kategoryzacji wydarzeń, czy doświadczeń, które zostały wskazywane przez klientów w umieszczanych przez nich komentarzach. Za punkt wyjście do klasyfikacji przypadków wybrano typologię zaproponowaną przez Pikkemaat i Schuckerta (2007), którzy na podstawie przeglądu literatury wyodrębnili kluczowe czynniki sukcesu istotne z punktu widzenia parków rozrywki. Stały się one punktem wyjścia do analizy w niniejszym badaniu i pozwoliły na typologizację antecedencji doświadczeń gości parku rozrywki Energylandia w Zatorze.

\section{WYNIKI BADANIA}

Prezentacja wyników badania obejmuje następujące trzy aspekty: prezentację charakteru doświadczeń (pozytywne vs. negatywne), określenie ich źródeł (antecedencji) i wskazanie efektów doświadczenia. W pierwszym etapie ustalono, jaki charakter miały doświadczenia poprzez ich klasyfikację do grupy zdarzeń pozytywnych lub negatywnych. Jak wynika z ryciny 1 82,03\% opisanych doświadczeń miała charakter pozytywny. 
Rycina 1. Charakter doświadczeń gości parku rozrywki Energylandia

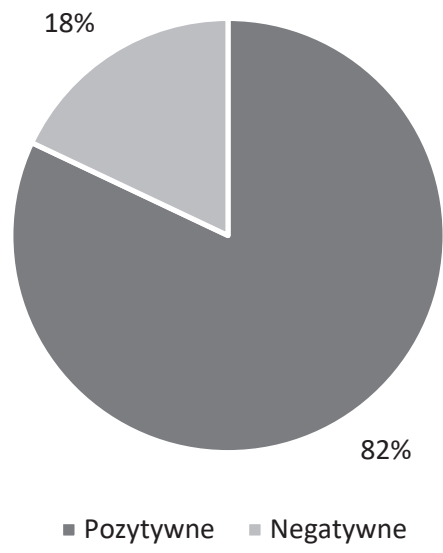

Źródło: opracowanie własne

Rycina 2. Antecedencje doświadczeń gości parku rozrywki Energylandia

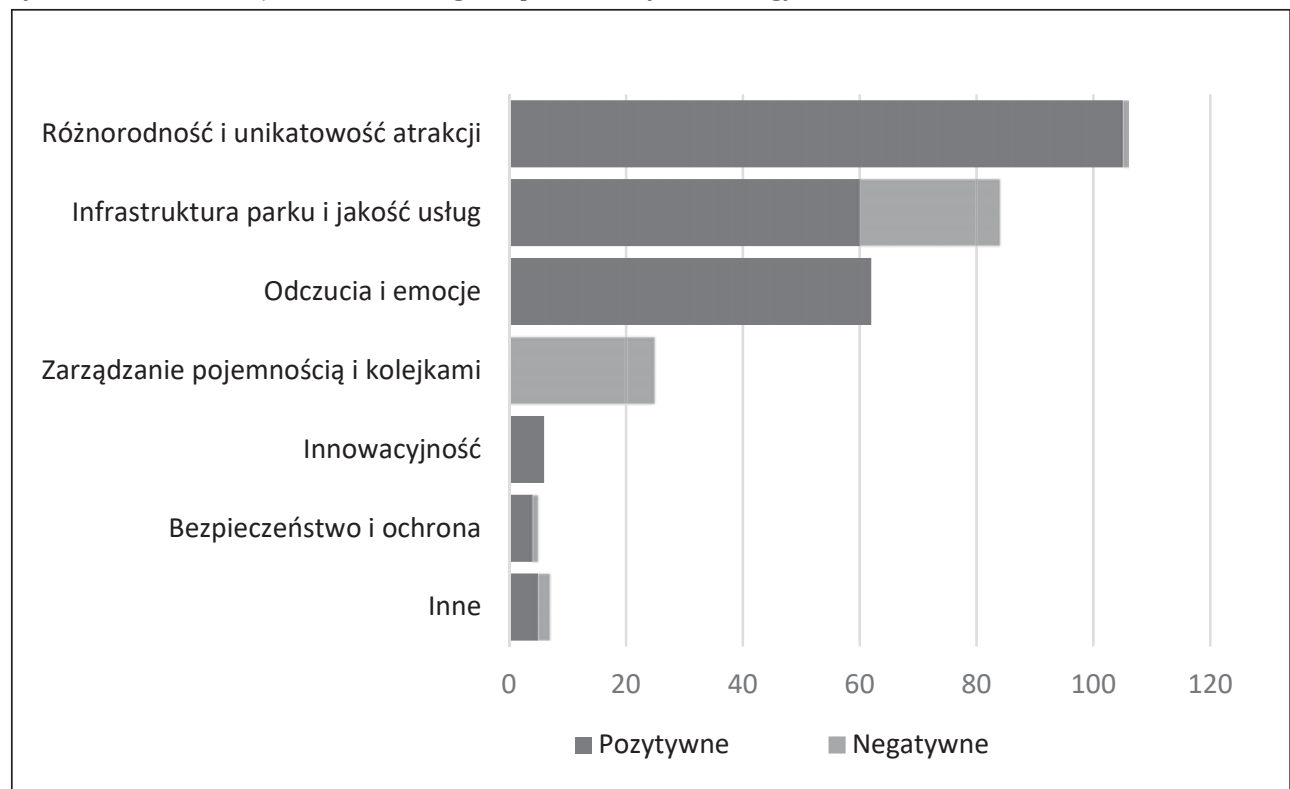

Źródło: opracowanie własne

Przedstawione na rycinie 2 antecedencje wskazują na te aspekty, które były najczęściej wspominane w komentarzach jako źródła doświadczeń. Wartości zaprezentowane na wykresie określają znaczenia poszczególnych typów zdarzeń w całości doświadczeń gości parku Energylandia. Bardzo często pozostawione opinie dotyczyły kilku aspektów, dlatego jeden komentarz mógł być przypisany jednocześnie do kilku kategorii. 
W ramach autorskiej kategoryzacji zdarzeń krytycznych wyróżniono następujące grupy antecedencji doświadczeń:

1. Różnorodność i unikatowość atrakcji, do której zostały zaklasyfikowane komentarze pokazujące znaczenie wybranych atrakcji, dla których warto odwiedzić park. Goście podkreślali wyjątkowość konkretnych atrakcji lub doceniali szeroki zakres oferty. Do tej kategorii przypisano łącznie 106 aspektów, co stanowi 35,93\% łącznej liczby zdarzeń. Tylko jedno zdarzenie odnosiło się do tych negatywnych doznań. Przykładowe komentarze:

\begin{abstract}
„Naprawdę fajne i pozytywne miejsce dla każdego. [...] Z kolejek najlepsza jest Zadra i Formuła 1. Polecam serdecznie”. Weronika L., Ostrów Wielkopolski, lipiec 2019.

„Największe wrażenie zrobiła na mnie Zadra. Jest potężna, majestatyczna, po prostu coś niesamowitego! Warto przejechać się na niej, wrażenie po przejeździe nie do opisania ...". Alina, październik 2019.

„Dawno nie była w tak rewelacyjnym miejscu, atrakcji tak duże, że ciężko zliczyć wszystkie, nawet przy małym ruchu turystycznym w tygodniu...”. Dagna, Meszno, wrzesień 2019.
\end{abstract}

Klienci odnosili się też do dostosowania oferty dla ludzi w każdym przedziale wiekowym, z podkreślaniem sformułowania „każdy znajdzie coś dla siebie” oraz zachwalali okazjonalne dekoracje.

„Pozycja obowiązkowa dla rodzin z dziećmi. Park jest nie lada atrakcją dla starszych i młodszych. Nikt nie będzie się nudził. Jeden z najlepszych parków, jak nie najlepszy. Polecam gorąco". Kajtek, wrzesień 2019.

2. Infrastruktura parku i jakość usług, w ramach której turyści podkreślali kwestie związane z infrastrukturą wspierającą główne atrakcje parku np. z parkingiem, systemem szafek, warunkami sanitarno-higienicznymi na terenie obiektu i gastronomią. Ten segment obejmuje 60 aspektów pozytywnych oraz 24 negatywnych, co daje 28,47\% udziału w całkowitej liczbie zdarzeń. Goście częściej doceniają przygotowanie infrastruktury parku podkreślając m.in.:

„Przed parkiem znajduje się duży parking dla autokarów i samochodów osobowych. Parkingowi sprawnie wskazują miejsce, logistyka na najwyższym poziomie. Przed wejściem na teren parku znajdują się bezpłatne toalety, na terenie parku również oraz szafki na telefon, czy wartościowe rzeczy...”. Wieczny Turysta, Toruń, czerwiec 2019.

„Szafki na pozostawienie rzeczy osobistych praktycznie przy każdej atrakcji”. Dagna, Meszno, wrzesień 2019.

„Wszystkie strefy idealnie rozplanowane i fantastycznie urządzone”. Andrzej, Toruń, sierpień 2019.

Jednak nie zawsze infrastruktura działa tak jak powinna:

„Chociaż nie do końca są uczciwi z szafkami na plecaki. [...] Nie informują, że szafka może być jedna na cały dzień”. Kinga M., Holandia, sierpień 2019. 
Do najczęściej wskazywanych wad infrastruktury wspierającej doświadczenia należy gastronomia.

„...jedzenie to jakaś tragedia. W pierwszy dzień jedliśmy frytki i kąski serowe - o ile frytki nie były aż takie złe, to kąski spowodowały u nas bóle brzucha do końca dnia. Na drugi dzień skusiliśmy się na gofry - z myślą, że gofrów nie da się popsuć. Niestety, Pani przy nas wkładała wcześniej zrobione gofry do mikrofalówki, co spowodowało, że były one po prostu niedobre - ... Nie polecamy nic jeść, wstyd, żeby w takim miejscu nie można było zjeść nic świeżego". Compass18043934227, Wrocław, wrzesień 2019.

Jakość usług odnosi się do zdarzeń związanych z poziomem obsługi pracowników kolejek oraz animatorów. Goście bardzo pozytywnie oceniają ich zaangażowanie:

\begin{abstract}
„Bardzo fajni animatorzy, którzy rozweselą dzień”. Weronika L., Ostrów Wielkopolski, lipiec 2019.

„Atrakcje na bardzo wysokim poziomie, zaplecze gastronomiczne też w porządku, ale najlepszą i największą robotę robią pracujący tam ludzie. Byłam z dwoma 12-letnimi chłopcami. Niestety tuż przed zamknięciem parku synowi (przez nieuwagę) w trakcie wyjścia z wagonika (atrakcja Kopalnia Złota) spadły okulary korekcyjne prosto do nurtu wody, po której płynął wagonik. Poinformowaliśmy personel, który naprawdę bardzo się przejął. Następnego dnia rano zadzwonił do nas Pan z biura z informacją, że okulary zostały znalezione. Godzinę później... kolejny telefon: jeden z pracowników Energylandii będzie w dniu dzisiejszym w Zabrzu i ... może nam zabrać okulary (dziękujemy Panu Zbyszkowi). Jesteśmy bardzo wdzięczni i ... w 100\% polecamy Energylandię". Joanna M., wrzesień 2019.
\end{abstract}

3. Odczucia i emocje, jakie towarzyszyły gościom odwiedzającym park. W ramach tej kategorii możemy wyróżnić takie aspekty jak poziom frajdy, rozumiany jako zabawę, poziom adrenaliny oraz wspomnienia, które pozostaną na długo w pamięci dzięki doświadczanym emocjom. W tej kategorii znalazło się 62 zdarzeń, które stanowią 21,02\% ogólnej liczby zdarzeń krytycznych. Jest to najczęściej wskazywana kategoria. Przykładowe komentarze:

„Najlepsza zabawa, jaką można sobie wyobrazić, najlepiej przyjść ze znajomymi, żeby poczuć moc wrażeń”. Dawid P., Zator, wrzesień 2019.

„Brak słów, żeby opisać zabawę w Energylandii, atrakcje i organizacja na najwyższym światowym poziomie. [...] Co do zabawy petarda, Zadra i Hyperion zdecydowanie trzeba mieć twarde serce [...]. Pozostałe atrakcje strefy ekstremalnej tez mega". Andrzej, Toruń, sierpień 2019.

„Emocje są nie do opisania. Jazda Hyperionem to coś, czego nie da się zapomnieć, ale tak, czy inaczej, Zadra to mój numer jeden". Maciej O., Łódź, wrzesień 2019.

Warto podkreślić, że respondenci bardzo często nie byli w stanie nazwać swoich emocji, ponieważ często miały one charakter skrajny, bliski euforii. Jednocześnie niektórzy podkreślali, że jednocześnie doświadczali negatywnych emocji, np. strachu, które pod wpływem atrakcji przechodziły w emocje pozytywne. Na przykład: 
„Wnuki zabrały mnie do Energylandii do Zatoru. Bardzo się bałam tak dużego parku, że będę zmęczona, ale poczułam w nim drugą młodość i dziecięcą radość. Polecam osobom w każdym wieku. Tam jest wspaniale". Grażyna, Ciechocinek, sierpień 2019.

4. Zarządzanie pojemnością i kolejkami, ta kategoria obejmuje komentarze dotyczące tłoku oraz obłożenia w parku. Dodatkowo wielu odwiedzających używało sformułowania „Jeden dzień to za mało”, co może oznaczać przesycenie atrakcji. W ramach tej grupy wskazano 25 zdarzeń i wszystkie mają negatywny charakter. Stanowią 8,47\% ogólnej liczby zdarzeń. Przykładowe komentarze pokazują, że goście mają czasami kłopot z wielkością parku i czasem oczekiwania.

„...W jeden dzień nie da się skorzystać z wszystkich atrakcji...”. Karolka K., sierpień 2019.

„Jedyne co to kolejki... Do reszty nie można się przyczepić... Powinien być limit w sprzedaży biletów. 5 min jazdy a stania 1,5 h”. Kinga M., Holandia, sierpień 2019.

„Park rozrywki - najlepiej odwiedzić w tygodniu i nie w wakacje. W takim miejscu trzeba przygotować się na kolejki do wszystkich atrakcji - od 10 do 70 minut”. Joanna Z., Łódź, sierpień 2019.

„W sezonie najlepiej udać się do wybranych atrakcji zaraz po otwarciu. Wtedy jeszcze nie ma kolejek. Między 12:00-16:00 w przypadku ładnej pogody czeka się od 1 do 1,5 h po to, aby przejechać się może 2 minuty. [...] W basenie masakra, ścisk straszny, wpuszcza się dzieci bez specjalnych pampersów do wody, nikt nie ma nad tym żadnej kontroli [...]”. Maja, Poznań, sierpień 2019.

Niektórzy respondenci wskazywali, że park próbuje rozwiązać problem okresowego przekraczania pojemności poprzez ciągłą rozbudowę i podejmując działania, które mogą ułatwić funkcjonowanie w warunkach dużej liczby odwiedzających. Na przykład:

„...plusem jest to, że otwiera się coraz więcej nowych atrakcji i można odwiedzić park wiele razy z rzędu". Dagna, Meszno, wrzesień 2019.

„Czasy oczekiwania często pokazywane są na wyświetlaczach”. Joanna Z., Łódź, sierpień 2019.

Nie wszystkie działania przynoszą jednak oczekiwane rezultaty:

„...Nie pomagają nawet zadaszenia, czekanie w upale jest męczące, nie ma nawet gdzie usiąść...”. Maja, Poznań, sierpień 2019.

5. Innowacyjność rozumianą jako ciągłą pracę nad atrakcjami oraz rozbudowywaniem stref o nowe kolejki, by klienci mogli wrócić, chociażby po to, aby je przetestować. Mamy tu tylko 6 adnotacji, co stanowi zaledwie 2,03\% łącznej liczby doznań. Przykładowe komentarze:

„W Halloween Night byliśmy ze znajomymi w parku i skorzystaliśmy z promocji dla przebranych [...] No i ten klimat! Większość ludzi przebranych w klimacie Halloween...". Crazy Wiewiora, Kielce, październik 2019. 
„... Z niecierpliwością czekam na przyszły sezon i otwarcie nowej strefy. Mam nadzieję, że pozytywnie mnie zaskoczy...”. Basia, wrzesień 2019.

6. Bezpieczeństwo i ochrona związane są z kwestiami zabezpieczenia atrakcji i tym podobnych. Jedynie 5 zdarzeń wspomnianych w komentarzach, stanowi tę kategorię, dlatego tez jej udział w całkowitej stanowi 1,69\%. Przykładowe komentarze:

„Park bezpieczny, widać, że porządna robota”. Aleks K., wrzesień 2019.

„...na pewno kiedyś tam wrócimy, na pewno po to, aby mój za mały w czasie pobytu synek, został wpuszczony na atrakcje, z których nie mógł skorzystać - brawo za przestrzeganie zasad". Małgorzata, wrzesień 2019.

„...Bezpieczne atrakcje, super aranżacje, czystość, pyszne jedzenie i niezapomniane wrażenia..." Bronisław, październik 2019.

7. Inne, które nie zostały przypisanie do żadnej kategorii, ponieważ dotyczyły innych wątków, często ciężkich do dopasowania do którejkolwiek z kategorii. Te doświadczenia stanowią zaledwie 2,37\%, a w ich skład wliczamy 5 pozytywnych i 2 negatywne.

Zbadano także efekty doświadczeń, które miały charakter deklaracji powrotu oraz polecenia parku przez odwiedzających. Wielu gości podkreślało także, że nie jest to ich pierwsza wizyta, i że planują kolejne w następnych sezonach. Z 150 umieszczonych komentarzy, aż 45 zawierało deklarację chęci powrotu lub rekomendacje dla innych klientów parku. Na przykład:

\footnotetext{
„Najlepsza rozrywka dla całych rodzin. [...] Polecamy, my za rok znów będziemy”. Monika, sierpień 2019.

„...jesteśmy bardzo zadowoleni, na pewno wrócimy w to miejsce...”. Agnieszka W., Katy Wrocławskie, sierpień 2019.

" [...] za rok na pewno kupimy bilety dwudniowe”. Karina, lipiec 2019.
}

Deklaracje powrotu są bardzo cenne z perspektywy właścicieli obiektu. Mimo że popyt na tego typu atrakcje ma charakter restytucyjny, to malejąca krańcowa użyteczność konsumpcji prowadzi zwykle do potrzeby odwiedzania nowych miejsc i testowania innych atrakcji i parków. Stabilność lub nawet wzrost liczby odwiedzających można uzyskać z jednej strony docierając do nowych odbiorców, a z drugiej utrzymując grupę lojalnych i powracających gości. Warunkiem tego drugiego jest jednak zaoferowanie klientom niezapomnianych doświadczeń.

\section{WNIOSKI}

Ze względu na swój charakter parki rozrywki są kluczowym podmiotem gospodarki doświadczeń (Ellis, Rossman, 2008). Charakteryzuje je teatralność, zanurzenie w określonej tematyce i polisensoryczność atrakcji (obraz, ruch, woda, dźwięki, przeciążenia, smaki i zapachy). Kładą one nacisk na hedonistyczne i przyjemne doświadczenia, w których emocje odwiedzających odgrywają ważną rolę. Jednak jak 
uważają Pikkemaat i Schuckert (2007: 201) parki rozrywki „są zaniedbywanym obszarem w badaniach nad turystyką".

Analiza źródeł doświadczeń pozwala dostrzec trzy główne przyczyny pozytywnych i negatywnych doświadczeń. Rdzeniem doświadczeń są główne atrakcje - kolejki, karuzele i in. Ich wykorzystywanie jest źródłem emocji przechodzących od strachu w euforię. Warunkiem dobrej zabawy jest tzw. infrastruktura wspierająca (parkingi, gastronomia, szafki), która wzmacnia lub osłabia pozytywne doświadczenie związane z pobytem w parku.

Jak wynika z przeprowadzonego badania, bardzo duże znaczenie mają dla turystów odczucia i emocje, tj. poziom zabawy czy adrenalina. W ramach tej kategorii najczęściej używano sformułowań: „świetna zabawa”, „niezapomniane emocje”, „super wrażenia". Porównując wyniki przeprowadzanej analizy z wcześniejszymi badaniami, można zauważyć podobieństwa w używanych sformułowaniach. Według Niu, Park i Kirilenko (2019) najczęstszymi przymiotnikami, które można było odczytać z komentarzy pozostawionych na portalu tripadvisor.com pod profilami takich parków jak Universal Studios, Disney World, czy Sea World są ang. great - świetny, wspaniały czy ang. amazing - niezwykły, niesamowity. Tego typu wyrazów używano również bardzo często w komentarzach pod profilem Energylandii.

Przyglądając się negatywnym komentarzom, prawie połowa $(47,17 \%)$ dotyczyła doświadczeń związanych ze staniem w kolejce do atrakcji. Ewidentnie jest to największy problem, z jakim boryka się park. Oczywiście ciężko jest rozładowywać kolejki, gdy pojemność jest ograniczona z powodu wymogów bezpieczeństwa. Należy jednak próbować szukać rozwiązania tej sytuacji, np. stosując nowoczesne rozwiązania bazujące na analizie lokalizacji i zarządzania czasem oczekiwania. Najłatwiejszą receptą w tej sytuacji wydaję się usprawnienie systemów pokazujących czas oczekiwania na zjazd. Jednak można iść o krok dalej i wprowadzić innowacyjne rozwiązanie w postaci aplikacji, która na wgranej mapie parku pokazywałby, jaki jest przybliżony czas czekania w kolejce, przez co klient mógłby rozplanować sobie podróż po parku i korzystanie z jego atrakcji w łatwy i przyjemny sposób. Innym pomysłem na rozwiązanie problemu kolejek jest ciągła rozbudowa parku i wprowadzenie nowych atrakcji.

Zgodnie z teorią atrybucji ustalono, że do kluczowych antecedencji pozytywnych doświadczeń należą emocje odczuwane przez korzystających z atrakcji. Do najważniejszych źródeł negatywnych doświadczeń należą problemy z czasem oczekiwania i gastronomią oferowaną na terenie parku. Wyniki te mogą być przydatne w projektowaniu doświadczeń gości odwiedzających nie tylko Energylandię w Zatorze, ale także inne parki rozrywki.

Ważnym aspektem, który został przebadany są efekty doświadczeń. Jak wynika $\mathrm{z}$ badania zadowoleni goście często deklarują chęć powrotu i rekomendowania parku innym. Komentarze zawierające wyrażenia „polecam”, czy „wrócę/wrócimy za rok” itp. pojawiły się w 45 opiniach, co oznacza, że około 30\% osób, które umieściły komentarz, wyraża chęć powrotu. Stanowią one zapowiedź sukcesu w kolejnych latach działania przedsiębiorstwa, a jednocześnie świadczą o poziomie lojalności. Można z nich wywnioskować, że znacząca część turystów w przyszłym sezonie zaplanuje podróż do Energylandii, tym razem na przykład na dłużej lub w towarzystwie rodziny i znajomych.

Jak wynika z przeprowadzonego badania, zastosowanie metody zdarzeń krytycznych, opartej na danych z portali internetowych, pozwala na ocenę doświadczeń 
konsumentów w parkach rozrywki. Dzięki zastosowaniu tego podejścia możliwe jest nie tylko określenie charakteru doświadczenia (pozytywne i negatywne), ale także jego struktury i spodziewanych efektów. Zastosowana metoda ma szereg zalet m.in. pozwala na uchwycenie opinii wyrażonych naturalnym językiem respondentów, identyfikację kluczowych wymiarów doświadczenia i ich kategoryzację, a także umożliwia sformułowanie rekomendacji działań naprawczych.

Przedstawione badanie oraz zastosowana metoda mają oczywiście pewne wady. Po pierwsze, dane gromadzone były tylko w pewnym wycinku czasu i nie mogą być traktowane jako pełne. Po drugie, metoda zdarzeń krytycznych, opiera się na subiektywnym sposobie klasyfikacji doświadczeń, co ma wpływ na uzyskane wyniki. Po trzecie, CIT jest retrospektywną metodą badawczą i w związku z tym jest obarczona błędami związanymi z pamięcią respondentów (Gremler, 2004). Dalsze badania powinny uwzględnić też bardziej zaawansowane metody grupowania, zliczania i prezentowania doświadczeń. Jak wynika z badania, największą wadą metody zdarzeń krytycznych, w kontekście stosowania do oceny doświadczeń, jest problem z interpretacją i porządkowaniem wydarzeń w kategorie. Jest to zadanie, które wymaga czasu oraz doświadczenia, co może być istotną barierą aplikacji tej metody w bieżącej działalności przedsiębiorstw.

Zastosowana metoda pozwoliła uchwycić heterogeniczne aspekty doświadczenia konsumpcyjnego w parkach rozrywki. Badanie doświadczeń przy wykorzystaniu metody zdarzeń krytycznych pozwala nie tylko określić istotne czynniki wpływających na doświadczenia (antecedencje), ale także przewidywać ich przyszłe zachowania związane z konkretnym usługodawcą.

\section{Literatura \\ References}

Adhikari, A., Bhattacharya, S. (2016). Appraisal of literature on customer experience in tourism sector: review and framework. Current Issues in Tourism, 19(4), 296-321. doi: https://doi. org/10.1080/13683500.2015.1082538

Agapito, D., Mendes, J., Valle, P. (2013). Exploring the conceptualization of the sensory dimension of tourist experiences. Journal of Destination Marketing \& Management, 2(2), 62-73. doi: https://doi.org/10.1016/j.jdmm.2013.03.001

Arora, R. (2012). A mixed method approach to understanding the role of emotions and sensual delight in dining experience. Journal of Consumer Marketing, 29(5), 333-343. doi: https:// doi.org/10.1108/07363761211247451

Baker, M.A., Kim, K. (2016). Other Customer Service Failures: Emotions, Impacts, and Attributions. Journal of Hospitality \& Tourism Research, 42(7), 1067-1085. doi: https://doi. org/10.1177/1096348016671394.

Bigné, J.E., Andreu, L., Gnoth, J. (2005). The theme park experience: An analysis of pleasure, arousal and satisfaction. Tourism Management, 26(6), 833-844. doi: https://doi.org/10.1016/ j.tourman.2004.05.006

Bos, L., McCabe, S., Johnson, S. (2013). Learning never goes on holiday. An exploration of social tourism as a context for experiential learning. Current Issues in Tourism, 18(9), 859-875. doi: https://doi.org/10.1080/13683500.2013.790878

Cetin, G., Bilgihan, A. (2016). Components of cultural tourists' experiences in destinations. Current Issues in Tourism, 19(2), 137-154. doi: https://doi.org/10.1080/13683500.2014. 994595

De Groote, P. (2011). Globalisation of commercial theme parks case. The Walt Disney Company. Applied Studies in Agribusiness and Commerce, 5(3-4), 21-28. doi: https://doi. org/10.19041/APSTRACT/2011/3-4/2 
Dong, P., Siu, N.Y.M. (2013). Servicescape elements, customer predispositions and service experience. The case of theme park visitors. Tourism Management, 36, 541-551. doi: https:// doi.org/10.1016/j.tourman.2012.09.004

Doroz-Tomasik, H., Jankowski, G. (2016). Parki tematyczne w Polsce - typologia i analiza globalnego sukcesu komercyjnego. Geography and Tourism, 4(1), 23-32

Dziadkowiec, J. (2006). Wybrane metody badania i oceny jakości usług. Zeszyty Naukowe Akademii Ekonomicznej w Krakowie, 717, 23-35.

Ellis, G. D., Rossman, J.R. (2008). Creating value for participants through experience staging: Parks, recreation, and tourism in the experience industry. Journal of Park and Recreation Administration, 26(4), 1-20.

Flanagan, J.C. (1954). The critical incident technique. Psychological Bulletin, 51(4), 327-358. doi: https://doi.org/10.1037/h0061470

Fu, X., Kang, J., Hahm, J.J., Wiitala, J. (2020). Investigating the consequences of theme park experience through the lenses of self-congruity and flow. International Journal of Contemporary Hospitality Management, 32(3), 1181-1199. doi: https://doi.org/10.1108/ ijchm-06-2019-0522

Gilmore, J., Pine, J. (2002). Differentiating hospitality operations via experiences. Why selling services is not enough. The Cornell Hotel and Restaurant Administration Quarterly, 43(3), 87-96. doi: https://doi.org/10.1177/0010880402433009

Gremler, D.D. (2004). The Critical Incident Technique in Service Research. Journal of Service Research, 7(1), 65-89. doi: https://doi.org/10.1177/1094670504266138

Jackson, M.S., White, G.N., Schmierer, C.L. (1996). Tourism experiences within an attributional framework. Annals of Tourism Research, 23(4), 798-810. doi: https://doi. org/10.1016/0160-7383(96)00003-5

Jackson, M. (2019). Utilizing attribution theory to develop new insights into tourism experiences. Journal of Hospitality and Tourism Management, 38, 176-183. doi: https://doi. org/10.1016/j.jhtm.2018.04.007

Kastenholz, E., Davis, D., Paul, G. (1999). Segmenting Tourism in Rural Areas. The Case of North and Central Portugal. Journal of Travel Research, 37(4), 353-363. doi: https://doi. org/10.1177/004728759903700405

Kruczek, Z. (2012). Parki tematyczne jako flagowe atrakcje turystyczne. Rozwój i globalizacja. Turystyka kulturowa, 3, 29-40.

Ma, J., Gao, J., Scott, N., Ding, P. (2013). Customer delight from theme park experiences. Annals of Tourism Research, 42, 359-381. doi: https://doi.org/10.1016/j.annals.2013.02.018

Niu, Y., Park, H., Kirilenko A. (2019). Theme Park Visitor Experience and Satisfaction. A Case of TripAdvisor Reviews of Three Theme Parks in Orlando. Travel and Tourism Research Association: Advancing Tourism Research Globally, 11. Pozyskano z https://scholarworks. umass.edu/ttra/2019/research_papers/11 (dostęp 19.08.2021).

Otto, J.E., Ritchie, J. (1996). The service experience in tourism. Tourism Management, 17(3), 165174. doi: https://doi.org/10.1016/0261-5177(96)00003-9

Pearce, P.L., Caltabiano, M.L. (1983). Inferring Travel Motivation from Travelers' Experiences. Journal of Travel Research, 22(2), 16-20. doi: https://doi.org/10.1177/ 004728758302200203

Pikkemaat, B., Schuckert, M. (2007). Success factors of theme parks - An exploration study. Preliminary Communication, 55(2), 197-208.

Rzeńca, P. (2012). Parki tematyczne jako czynnik rozwoju gospodarki. Identyfikacja zjawiska. Prace Naukowe Uniwersytetu Ekonomicznego we Wrocławiu, 244, 405-415.

Schmitt, B. (1999). Experiential Marketing. Journal of Marketing Management, 15(1-3), 53-67. doi: https://doi.org/10.1362/026725799784870496

Stangierska, D., Górska-Warsewicz, H. (2016). Marketing tradycyjny, relacji i doświadczeń marek usługowych i produktowych - komunikacja z konsumentem na portalu Facebook. Problemy Zarzadzania, 58(1/2), 125-137. doi: https://doi.org/10.7172/1644-9584.58.9

Tchorek, Z., Kulykovets, O., Górska-Warsewicz, H. (2016). Theme Parks in Europe and Poland in the Tourists Perception. Ekonomiczne Problemy Turystyki, 34, 285-295. doi: https://doi. org/10.18276/ept.2016.2.34-24 
Tung, V.W.S., Ritchie, J.B. (2011). Exploring the essence of memorable tourism experiences. Annals of Tourism Research, 38(4), 1367-1386. doi: https://doi.org/10.1016/j.annals.2011.03.009

Wei, W., Zheng, Y., Zhang, L., Line, N. (2021). Leveraging customer-to-customer interactions to create immersive and memorable theme park experiences. Journal of Hospitality and Tourism Insights, ahead-of(ahead-of-print). doi: https://doi.org/10.1108/jhti-10-20200205

Wu, H.C., Li, M.Y., Li, T. (2014). A Study of Experiential Quality, Experiential Value, Experiential Satisfaction, Theme Park Image, and Revisit Intention. Journal of Hospitality \& Tourism Research, 42(1), 26-73. doi: https://doi.org/10.1177/1096348014563396

Zainol, N.A., Lockwood, A. (2014). Understanding Service Experience. A Critical Incident Technique Approach. Academic Research International, 5(4).

Marta Klimaszyk, absolwentka, Uniwersytet Ekonomiczny w Poznaniu, Instytut Gospodarki Międzynarodowej, Katedra Międzynarodowych Stosunków Gospodarczych. W roku 2021 obroniła pracę dyplomową poświęconą zarządzaniu doświadczeniem konsumenta w parkach rozrywki. Jej zainteresowania badawcze obejmują problematykę konkurencyjności gospodarki turystycznej, zarządzania w turystyce oraz doświadczeń konsumentów.

Marta Klimaszyk, graduate Poznań University of Economics and Business, Institute of International Business and Economics, Department of International Economics. In 2021 she completed her diploma thesis on consumer experience management in theme parks. Her research interests include tourism industry competitiveness, tourism management and consumer experience.

ORCID: https://orcid.org/0000-0002-8621-4493

Adres/address:

Uniwersytet Ekonomiczny w Poznaniu

Instytut Gospodarki Międzynarodowej

al. Niepodległości 10

61-875 Poznań

e-mail: marta.klimaszykk@gmail.com

Marcin Olszewski, dr, adiunkt, Uniwersytet Ekonomiczny w Poznaniu, Instytut Gospodarki Międzynarodowej, Katedra Międzynarodowych Stosunków Gospodarczych. W 2011 r. obronił rozprawę doktorską poświęconą zarządzaniu wiedzą w procesie konkurowania przez jakość na rynku hotelarskim. Jego zainteresowania badawcze obejmują problematykę współpracy uczelni wyższych z przedsiębiorstwami, zarządzania wiedzą, transferu wiedzy, konkurencyjności gospodarki turystycznej. Brał udział w kilku krajowych i międzynarodowych projektach badawczych dotyczących gospodarki turystycznej ( $w$ tym finansowanych przez Ministerstwo Nauki i Szkolnictwa Wyższego i Narodowe Centrum Nauki).

Marcin Olszewski, PhD, is an assistant professor in the Poznań University of Economics and Business, Institute of International Business and Economics, Department of International Economics, Poland. He obtained his $\mathrm{PhD}$ in 2011 with a doctoral thesis on knowledge management in hospitality industry. His areas of research include university-industry collaboration, knowledge management, tourism industry competitiveness, economics of tourism enterprise. He has participated in several research projects on the tourism and hospitality industry (including those financed by the Ministry of Science and Higher Education and the National Science Center).

ORCID: https://orcid.org/0000-0001-9041-9953

\section{Adres/address:}

Uniwersytet Ekonomiczny w Poznaniu

Instytut Gospodarki Międzynarodowej

al. Niepodległości 10

61-875 Poznań

e-mail: marcin.olszewski@ue.poznan.pl 